\title{
Perancangan Sensor Kapasitor Dan Penggunaan Sensor Warna Sebagai Pendeteksi Tingkat Kematangan Biji Kopi Kawi Roasting Menggunakan Logika Fuzzy Berbasis Arduino
}

\author{
Bahril Ilmid Nugroho ${ }^{1}$, Azam Muzakhim ${ }^{2}$, Lis Diana ${ }^{3}$ \\ ${ }^{1,2}$ Program Studi Jaringan Telekomunikasi Digital, \\ ${ }^{3}$ Program Studi Teknik Telekomunikasi, \\ Jurusan Teknik Elektro, Politeknik Negeri Malang, Indonesia \\ bahrililmidnugroho@gmail.com, ${ }^{2}$ azam@polinema.ac.id, ${ }^{3}$ lisdianamustafa16@gmail.com
}

\begin{abstract}
Coffee is one of the most popular drinks in Indonesia because of its taste and aroma. Coffee in its presentation has different types which are determined by the coffee beans maturity level during roasting, including light roast, medium roast and dark roast. Each of the three types of roasting profiles has a different level of moisture in the beans. The use of a roaster machine to determine the coffee beans maturity level often uses temperature and roasting time settings. Knowing the capacitance value in determining the roasting level is expected to increase the accuracy of the roasting level. In this study, a capacitor sensor consisting of two parallel copper plates was designed to determine the roasted coffee beans maturity level. The frequency value and color sensor in the system were used to determine the basic value of the classification of Kawi coffee beans maturity level in the fuzzy system. Based on the results, namely at a parallel capacitor sensor distance of $2 \mathrm{~cm}$, the oscilloscope readings of dark maturity have a frequency range between $201 \mathrm{KHz}$ $-213 \mathrm{KHz}$, medium in the range $179 \mathrm{KHz}-206 \mathrm{KHz}$ and light $178 \mathrm{KHz}-200 \mathrm{KHz}$. Meanwhile, the Arduino frequency counter readings at the dark maturity level in range of $204 \mathrm{KHz}-234 \mathrm{KHz}$, medium in range of $210 \mathrm{KHz}-227 \mathrm{KHz}$ and light at $205 \mathrm{KHz}-223 \mathrm{KHz}$. The results of the maturity level classification of Kawi coffee beans with fuzzy values for dark $<43.50,43.50<$ medium $<174$ and light $>$ 174.

Keywords-Coffee Roasting, Capacitance Sensor, Fuzzy, Arduino
\end{abstract}

Abstrak-Kopi merupakan salah satu minuman yang sangat di gemari di Indonesia karena rasa dan aromanya. Kopi dalam penyajiannya memiliki jenis berbeda yang ditentukan oleh tingkat kematangan biji kopi saat roasting antara lain light roast, medium roast dan dark roast. Dari ketiga jenis profil roasting tersebut masing-masing memiliki tingkat kadar air dalam biji yang berbeda. Penggunaan mesin roaster untuk menentukan tingkat kematangan biji kopi sering menggunakan pengaturan temperatur dan waktu roasting. Dengan mengetahui nilai kapasitansi dalam menentukan tingkat roasting diharapkan akan menambah keakurasian tingkat roasting. Pada penelitian ini dirancang sebuah sensor kapasitor yang terdiri dari dua keping plat tembaga yang sejajar untuk menentukan tingkat kematangan biji kopi yang telah diroasting.Nilai frekuensi dan sensor warna pada system digunakan untuk menentukan nilai dasar klasifikasi tingkat kematangan biji kopi kawi pada system fuzzy. Berdasarkan hasil penelitian yakni pada jarak sensor kapasitor sejajar sebesar $2 \mathrm{~cm}$ pembacaan osiloskop tingkat kematangan dark memliki range frekuensi antara $201 \mathrm{KHz}-$ $213 \mathrm{KHz}$, medium pada range $179 \mathrm{KHz}-206 \mathrm{KHz}$ dan light $178 \mathrm{KHz}-200 \mathrm{KHz}$. Sedangkan pada pembacaan frequency counter arduino pada tingkat kematangan dark memiliki range $204 \mathrm{KHz}-234 \mathrm{KHz}$, medium pada range $210 \mathrm{KHz}-227 \mathrm{KHz}$ dan light pada $205 \mathrm{KHz}-$ $223 \mathrm{KHz}$. Hasil klasifikasi jenis tingkat kematangan biji kopi kawi dengan nilai fuzzy untuk dark $<43.50,43,50<$ medium $<174$ dan light $>174$.

Kata Kunci-Kopi sangria, Sensor Kapasitor, fuzzy, Arduino

\section{PENDAHULUAN}

Kopi merupakan salah satu minuman yang sangat di gemari oleh masyarakat Indonesia karena rasa dan aromanya. Minuman ini di gemari oleh segala umur secara turun temurun. Jenis kopi yang ada di Indonesia memiliki ciri khas tersendiri tergantung dari kontur tanah, letak ketinggian tanah terhadap permukaan laut, cara penanaman hingga proses pemanenan. Dalam penentuan lokasi tanam untuk tanaman kopi di Indonesia saat ini umumnya dapat tumbuh baik pada ketinggian tempat di atas $700 \mathrm{~m}$ di atas permukaan laut (dpl) [1]. Untuk penanaman pada tanaman kopi ada beberapa hal yang harus dilakukan seperti pengajiran, jarak tanam, lubang tanam, pengendalian erosi hingga penaung untuk memaksimalkan hasil panen [2].

Biji kopi dari setiap jenis kopi dalam penyajiannya memiliki beberapa jenis yang ditentukan oleh tingkat kematangan biji kopi saat di roasting antara lain light roast, medium roast dan dark roast Proses roasting adalah proses pembentukan rasa dan aroma pada biji kopi. Apabila biji kopi memiliki keseragaman dalam ukuran, specific gravity, tekstur, kadar air dan struktur kimia, maka proses penyangraian akan relatif lebih mudah untuk dikendalikan. Kenyataannya, biji kopi memiliki perbedaan yang sangat besar, sehingga proses penyangraian merupakan seni dan memerlukan ketrampilan dan pengalaman sebagaimana permintaan konsumen [3]. 
Dalam proses menyangrai biji kopi di dalam mesin roaster memerlukan beberapa kalibrasi yaitu berupa suhu dan waktu berdasarkan profil roasting mana yang akan dipilih. Untuk light roast menggunakan fast roast yaitu antara 8-9 menit, medium roast menggunakan complex roasting antara 12-13 menit dan dark roast menggunakan slow roasting dengan kisaran waktu 14-15 menit. Pengaturan suhu tergantung pada masa jenis dari biji kopi yang akan diroasting semakin besar masa jenis maka semakin besar pula suhu yang akan digunakan [1].

Perbedaan biji kopi yang telah diroasting berdasarkan profilnya dapat dilihat langsung, semakin gelap biji kopinya maka semakin pahit rasanya namun dalam penyajiannya yang sangat penting adalah rasa dan aroma dari kopi tersebut dan ini berhubungan dengan bnyaknya kadar air yang tersisa di dalam jenis masing-masing biji kopi tersebut . Dengan mengetahui nilai kapasitansi dari setiap profil roasting tersebut diharapkan dapat menjadi variable tambahan dalam penentuan dan klasifikasi profile roasting biji kopi berdasarkan nilai kapasitansi dan frekuensi [4][5].

Salah satu caranya adalah membuat alat pendeteksi tingkat roasting pada biji kopi dengan memanfaatkan nilai frekuensi serta sensor warna berbasis fuzzy logic [6].

Rangkaian pendeteksi tingkat roasting terdiri dari rangkaian CMOS 4069 resistor dan kapasitor (RC) dimana nilai dari kapasitor akan berubah-ubah sesuai dengan bahan dielektrik yang masuk di dalam 2 plat logam kapasitor yang nantinya akan mengubah nilai frekuensi [7][8].

Logika Fuzzy adalah suatu proses pengambilan keputusan berbasis aturan yang bertujuan untuk memecahkan masalah, dimana system tersebut sulit untuk dimodelkan atau terdapat ambiguitas dan ketidak jelasan yang berlimpah. Kontroler logika fuzzy dikategorikan dalam control cerdas (intelligent control). Unit logika fuzzy memiliki kemampuan menyelesaikan masalah perilaku system yang komplek, yang tidak dimiliki oleh kontroler konvensional [9][10]. Oleh karena itu, logika fuzzy sangat tepat digunakan untuk mendeteksi jenis biji kopi sesuai dengan tingkat roastingnya

\section{METODE}

\section{A. Blok Diagram Sistem}

Rancangan yang akan dilakukan pada penelitian ini akan ditunjukkan pada Gambar 1.



Gambar 1. Blok diagram sistem

- Biji kopi merupakan bahan yang digunakan untuk penelitian dan akan mengubah nilai kapasitif dari sensor. Ada 3 jenis biji kopi yaitu light roast, medium roast dan dark roast
- Sensor kapasitif akan memberikan sebuah nilai kapasitansi berdasarkan jenis biji roasting yang dimasukkan.

- Sensor Warna akan mendeteksi intesitas warna yang ada pada biji kopi sesuai sengan warna dasar digital yang ada yaitu red, green dan blue

- Rangkaian RC akan menghasilkan sinyal feedback yaitu berupa frekuensi resonan yang berulang ulang

- CMOS sebagai inverter akan mencharge kapasitor melalui gerbang NOT dengan cara mendapat kan impedansi masukan yg besar dari salah satu gerbang.

- Osilator merupakan rangkaian yang terdiri dari RC dan IC CMOS dimana akan memberikan keluaran yang amplitudonya berubah ubah secara periodic dengan waktu.

- Arduino Uno merupakan microcontroller yang berfungsi untuk mendeteksi sinyal frekuensi dari osilator

- Lcd 16x2 digunakan untuk menapilkan data dari Arduino uno

Frekuensi counter di rangkai menggunakan Arduino dan OLED sebagai pendeteksi frekuensi

\section{B. Perencanaan Hardware}

Gambar 2 menjelaskan tentang diagram blok sistem pada penelitian ini.

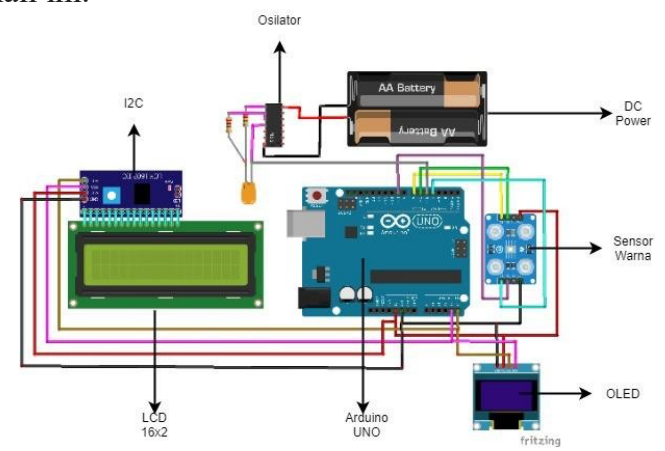

Gambar 2. Perancangan desain hardware keseluruhan

Gambar 3 dan Gambar 4 menunjukkan skema rangkaian dari alat pendeteksi tingkat kematangan biji kopi, sebagai berikut:

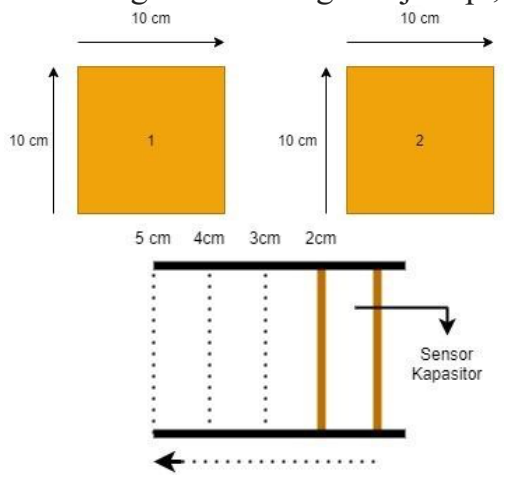

Gambar 3. Perencanaan Sensor Kapasitor

Pada sensor kapasitor menggunakan plat tembaga dengan ukuran $10 \mathrm{~cm}$ x $10 \mathrm{~cm}$. Penentuan jarak pada kapasitor dibagi 
menjadi $2 \mathrm{~cm}, 3 \mathrm{~cm}$, $4 \mathrm{~cm}$ dan $5 \mathrm{~cm}$ dimana biji kopi akan diletakkan di dalam sensor kapasitor dengan beberapa variasi jarak.

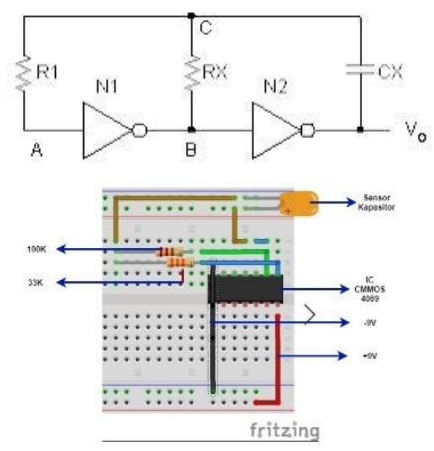

Gambar 4. Rangkaian Osilator RC

Rancangan rangkaian osilator RC terdiri dari beberapa komponen yaitu resistor dengan nilai sebesar $33 \mathrm{k} \Omega$ dan $100 \mathrm{k} \Omega$, project board, IC CMOS 4069, sensor kapasitor dan kabel jumper [9]. Proses perancangan rangkaian osilator dibuat dengan menggunakan software fritzing [10][11].

Pada rancangan rangkaian osilator RC IC CMOS4069 menggunakan 2 gerbang NOT sebagai inverter untuk menghasilkan osilasi. Dengan nilai resistor yang sesuai maka kapasitor dapat mentrigger gerbang NOT 1 untuk melakukan osilasi kembali dengan memanfaatkan delay propagasi antara gerbang NOT 1 dan gerbang NOT 2 [12][13].

Untuk mendeteksi tingkat kematangan biji kopi ada 2 cara yaitu menggunakan sensor kapasitor dan sensor warna. Sensor kapasitor dihubungkan ke rangkaian osilator RC, lalu hasil dari rangkaian osilator $\mathrm{RC}$ berupa frekuensi akan tersambung pada pin digital 5 di arduino. Sedangkan pembacaan sensor warna dibaca melalui beberapa pin digital pada Arduino, ditunjukkan pada Tabel 1 berikut ini:

TABEL I

\begin{tabular}{cc} 
Keterkaitan PIN ARduINO DAN PN TCS230 \\
\hline Pin Arduino & Pin TCS230 \\
\hline 4 & S0 \\
6 & S2 \\
7 & S3 \\
8 & Out \\
9 & S1 \\
\hline
\end{tabular}

Hasil output berupa klasifikasi tingkat kematangan pada biji kopi berdasarkan perubahan nilai frekuensi dan sensor warna yang akan tertampil pada LCD 16x2 dimana digunakan untuk tampilan hasil fuzzi dan jenis tingkat kematangan sedangkan OLED untuk tampilan frekuensi.

\section{Perencanaan Fuzzy}

a) Fuzzifikasi

- Fuzzifikasi Frekuensi

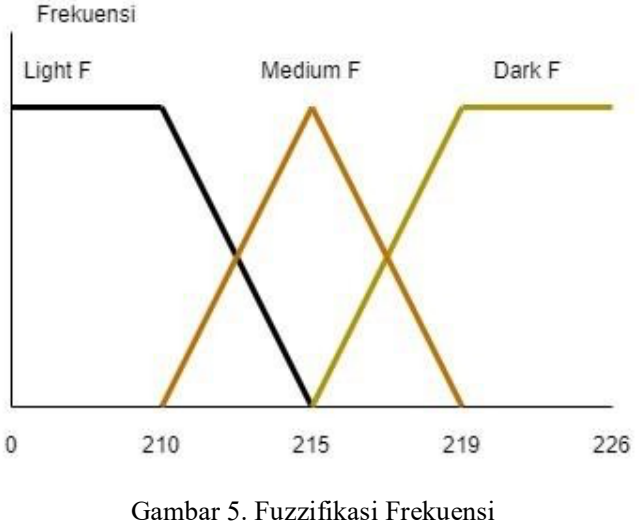

- $\quad$ Fuzzifikasi Sensor Warna

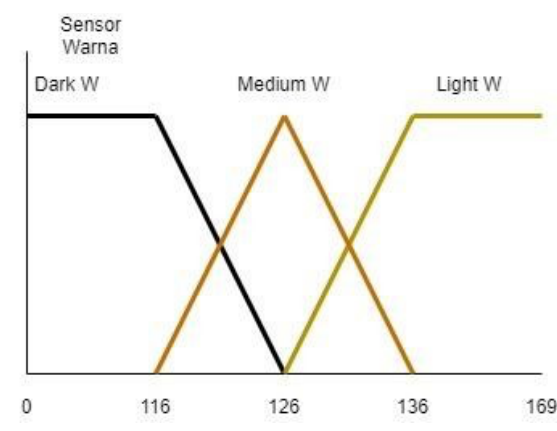

Gambar 6. Fuzzifikasi Sensor Warna

b) Logika Fuzzy



c) Defuzzifikasi $C O G=\frac{\sum_{x=a}^{b} \mu_{A}(\chi) x}{\sum_{x=a}^{b} \mu_{A}(\chi)}$

\begin{tabular}{|l|l|c|}
\hline Pembagian & Cog & Cogx \\
\hline $0+29+58+87$ & 174 & $(1)^{4}$ \\
\hline $116+145+174+203$ & 638 & 5 \\
\hline $232+261+290+319+348$ & 1450 & 4 \\
\hline $0+29+58+87$ & 174 & 5 \\
\hline $116+145+174+203+232$ & 870 & 6 \\
\hline $261+290+319+348+377+406$ & 2001 & \multicolumn{2}{|l|}{} \\
\hline
\end{tabular}




\section{HASIL DAN PEMBAHASAN}

\section{A. Hasil Implementasi Hardware}

Gambar 7 Sensor Kapasitif terdiri dari dua plat tembaga dengan ukuran $10 \mathrm{~cm} \times 10 \mathrm{~cm}$ dengan rentang jarak yang telah di tentukan yaitu mulai dari $2 \mathrm{~cm}$ hingga $5 \mathrm{~cm}$. Pengujian dilakukan dengan memasukkan tiga macam tingkat kematangan biji kopi yaitu dark, medium dan light ke dalam sensor kapasitif. Dengan menggunakan dua kabel jumper yang terpasang pada sensor kapasitor rangkaian osilator RC akan melakukan proses osilasi antara dua gerbang NOT.

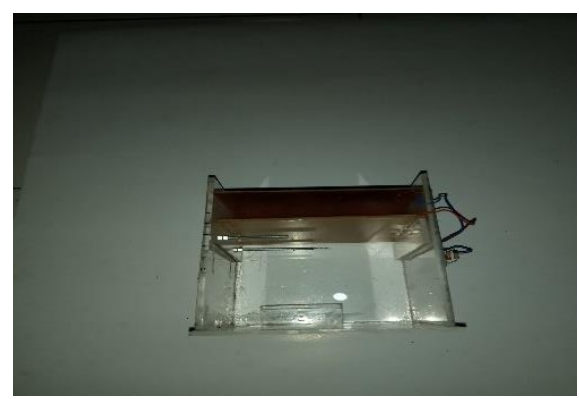

Gambar 7. Sensor Kapasitor

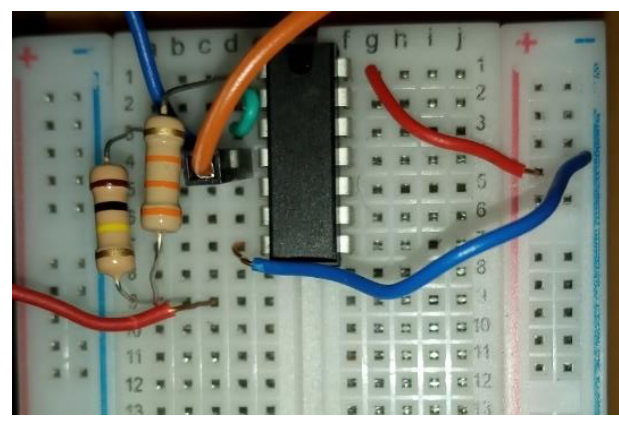

Gambar 8. Rangkaian Osilator RC CMOS 4069

Gambar 8 menunjukkan terdapat rangkaian osilator RC CMOS 4069 yang digunakan untuk mendeteksi frekuensi dari biji kopi yang telah dimasukkan pada sensor kapasitif.

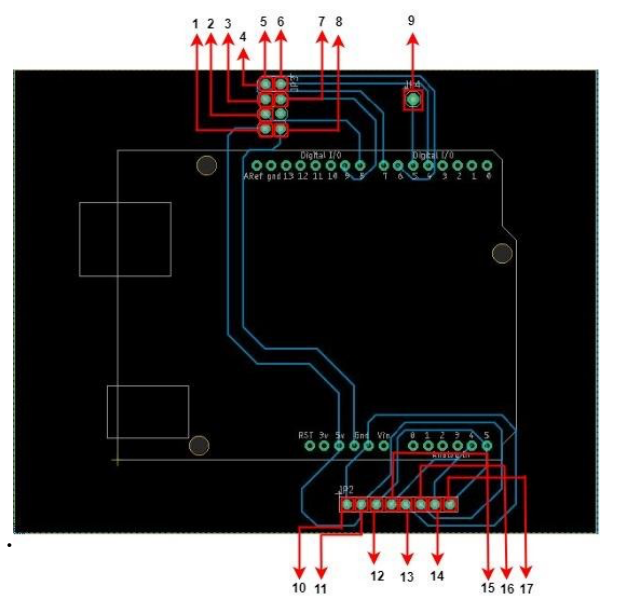

Gambar 9. Hasil Implementasi Layout Sistem

\section{B. Pengujian Frekuensi}

Pengujian pada rangkaian osilator RC dilakukan sebanyak sepuluh kali dengan variasi jarak plat kapasitor antara $2 \mathrm{~cm}$ hingga $5 \mathrm{~cm}$ guna mengetahui berapa frekuensi yang dihasilkan. Deteksi frekuensi menggunakan dua alat yaitu osiloskop yang langsung terhubung ke rangkaian osilator RC dan frequency counter arduino agar nilai frekuensi yang dibaca dapat digunakan untuk nilai dasar dalam penenetuan keanggotaan fuzzy.

Pengujian dilakukan sebanyak sepuluh kali dengan tiga macam tingkat kematangan biji kopi yaitu dark, medium dan light serta jarak antara plat kapasitor sejajar dimulai dari $2 \mathrm{~cm}$ hingga $5 \mathrm{~cm}$ menggunakan osiloskop dan frequency counter Arduino. Diantara beberapa variasi jarak plat kapasitor sejajar yang diuji dan hasil pembacaan frekuensi pada osiloskop dan frequency counter arduino menunjukkan bahwa pada jarak $2 \mathrm{~cm}$ rentang hasil pembacaan antara biji kopi dark, medium dan light tinggi dibandingkan dengan variasi jarak yang lain. Perbedaan selisih ditunjukkan pada grafik trend, Selisih yang tinggi akan mempermudah dalam penentuan keanggotaan fuzzy.

\begin{tabular}{|lrrrr|}
\hline Percobaan & Dark & \multicolumn{3}{c|}{ Medium } \\
& 1 & 225 & 227 & 217 \\
\hline & 2 & 226 & 219 & 215 \\
\hline & 3 & 225 & 215 & 214 \\
\hline & 4 & 216 & 211 & 212 \\
\hline & 5 & 234 & 224 & 223 \\
\hline & 6 & 227 & 211 & 206 \\
\hline & 7 & 223 & 210 & 211 \\
\hline & 8 & 204 & 219 & 209 \\
\hline & 9 & 219 & 210 & 205 \\
\hline & 10 & 218 & 211 & 206 \\
\hline Rata-rata & & 221.7 & 215.7 & 211.8 \\
\hline Minimal & & 204 & 210 & 205 \\
\hline Maksimal & & 234 & 227 & 223 \\
\hline
\end{tabular}

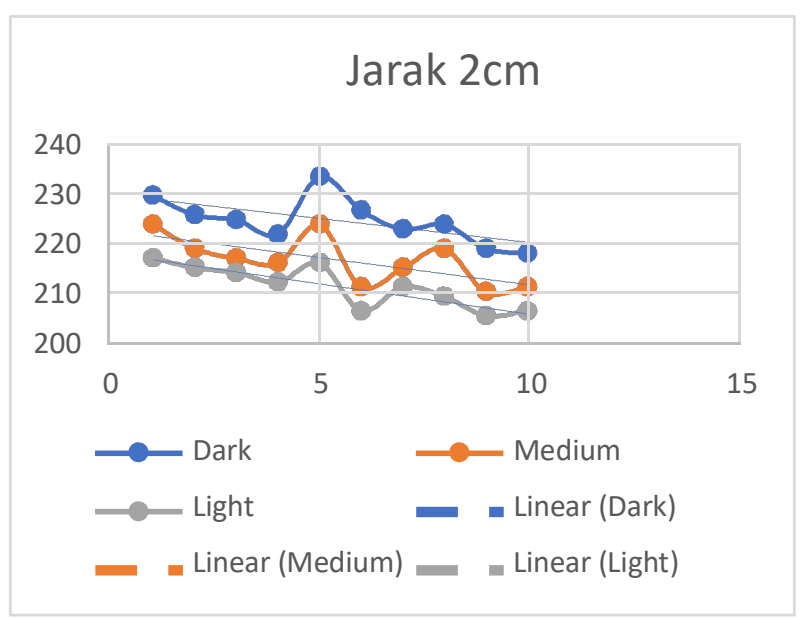

Gambar 10. Hasil Pembacaan Frekuensi Pada Frequency Counter Arduino Dengan Jarak plat kapasitor sebesar $2 \mathrm{~cm}$

\section{KESIMPULAN}

1. Nilai pada sensor kapasitor digunakan di dalam rangkaian osilator untuk mendapatkan nilai frekuensi. Output rangkaian osilator berupa frekuensi akan dibaca oleh frequency counter pada Arduino yang akan menjadi nilai dasar untuk sistem fuzzy. Untuk tingkat kematanngan dark meiliki range nilai, light dengan range $205 \mathrm{KHz}-217$ 
$\mathrm{KHz}$, medium dengan range $210 \mathrm{KHz}-224 \mathrm{KHz}$ dan dark sebesar $218 \mathrm{KHz}$ - $234 \mathrm{KHz}$. Pada perhitungan nilai kapasitansi tingkat kematangan dark meiliki nilai rata-rata $14 \mathrm{uF}$, medium dengan nilai $16 \mathrm{uF}$ dan light dengan nilai 17 $\mathrm{uF}$.

2. Dalam mengimplementasikan algoritma logika fuzzy berdasarkan dua masukan nilai dasar sistem fuzzy yaitu frekuensi dan nilai sensor warna yang didapat maka ditentukan nilai keanggotaan dari masing-masing tingkat kematangan biji kopi. Dalam pengujian sistem fuzzy untuk tingkat kematangan dark memiliki nilai frekuensi dengan range nilai keanggotaan, Dark $<210 \mathrm{KHz}, 210 \mathrm{KHz}<$ Medium $<215 \mathrm{KHz}$ dan light $219 \mathrm{KHz}<$ Light. Sedangkan pada sensor warna dalam pengujian sistem fuzzy untuk tingkat kematangan dark memiliki range nilai keanggotaan, Dark $<116$, untuk medium dengan range $116<$ Medium $<$ 136 dan dark dengan range $136<$ Light.

3. Hasil pengujian alat dengan logika fuzzy secara keseluruhan pada penelitian telah menunjukkan kesesuaian antara nilai masukaan sensor warna dan rangkaian osilator terhadap hasil klasifikasi jenis tingkat kematangan biji kopi kawi dengan nilai fuzzy untuk dark $<43.50$, 43,50< medium $<174$ dan light $>174$. Tingkat kesesuaian antara nilai masukan dan hasil keluaran sebesar $90 \%$.

\section{REFERENSI}

[1] Layla Febri H, Yuliana Setiarini, Haki Midia , "Alat Pendeteksi Kualitas Biji Kopi Papain(Kopi Citarasa Kopi Luwak Tanpa Menggunakan Luwak) Dengan Metode Pengukuran Nilai Kapasitansi”, 2015.

[2] A. Windiarto and K. Wardani, "Rancang Bangun Voice Over Internet Protocol dan GSM Gateway Berbasis Raspberry Pi”, 2019.

[3] F. Hidayat, "IMPLEMENTASI FUZZY PADA SISTEM PENGIDENTIFIKASI", 2018.

[4] L. D. Mustafa, S. H. Susilo, and R. H. Y. Perdana, "Detection of Salak Chips readiness on vacuum frying machines based on vacuum pipe temperature and frying time," in IOP Conference Series: Materials Science and Engineering, 2020, vol. 732, no. 1.

[5] R. Arissandi, D. I. E. Yudaningtyas MT., and M. Ir. Retnowati, "Implementasi Kontrol Logika Fuzzy (KLF) Sebagai Pengendali Suhu Sistem Pasteurisasi Kuning Telur Cair", 2014.

[6] I. Sofi'i, "Rancang Bangun Mesin Penyangrai Kopi dengan Pengaduk Berputar", 2014.

[7] N. Joko, J. Lumbanbatu, and R. Sri, "Pengaruh Suhu dan Lama Penyangraian Terhadap Sifat Fisik Mekanis Biji Kopi Robusta”, 2009.

[8] E. N. Lestariawan, "Design of Home Electrical Device Controllers Using Fuzzy Logic Based on Raspberry Pi and the Web", Jurnal Jartel, vol. 6, no. 1, pp. 50-56, May 2018.

[9] A. A. Fahruri, "Analisis Dielektrik Kapasitor Keping Sejajar Berbahan Dasar Buah Tomat”, 2017.

[10] R. N. Alam, “ Design of System for Determining Corn Seed Color Quality Standards using the Fuzzy Logic Method through the Localhost Network", Jurnal Jartel, vol. 8, no. 1, pp. 62-70, Mar. 2019.

[11] W. Bridge, "Osilator dan Sumber Sinyal," pp. 1-16, 2012.
[12] G. Description and O. Code, "CD4049UBC CD4050BC Hex Inverting Buffer Hex NonInverting Buffer Ordering Code", 1999.

[13] L. N. Rohmah, H. Nugroho, and K. Wardani, "Rancang Bangun Modul Pembelajaran Oscillator", 2018.

[14] Junaidi and Y. D. Prabowo, "Project Sistem Kendali Elektronik Berbasis Arduino", 2018.

[15] D. A. Rahmawati, "Penerapan Fuzzy Logic Dengan Menggunakan Metode Mamdani Untuk Memprediksi Kualitas Kopi,” 2015. 